This item was submitted to Loughborough's Research Repository by the author.

Items in Figshare are protected by copyright, with all rights reserved, unless otherwise indicated.

\title{
The financing of small firms: different continents, the same problems?
}

\section{PLEASE CITE THE PUBLISHED VERSION}

http://www.sacredheart.edu/pages/12146_neje_new_england_journal_of_entrepreneurship_.cfm

\section{PUBLISHER}

(c) Sacred Heart University

VERSION

AM (Accepted Manuscript)

LICENCE

CC BY-NC-ND 4.0

\section{REPOSITORY RECORD}

Boocock, Grahame, and Ismail Wahab. 2019. "The Financing of Small Firms: Different Continents, the Same Problems?”. figshare. https://hdl.handle.net/2134/8277. 
This item was submitted to Loughborough's Institutional Repository (https://dspace.lboro.ac.uk/) by the author and is made available under the following Creative Commons Licence conditions.

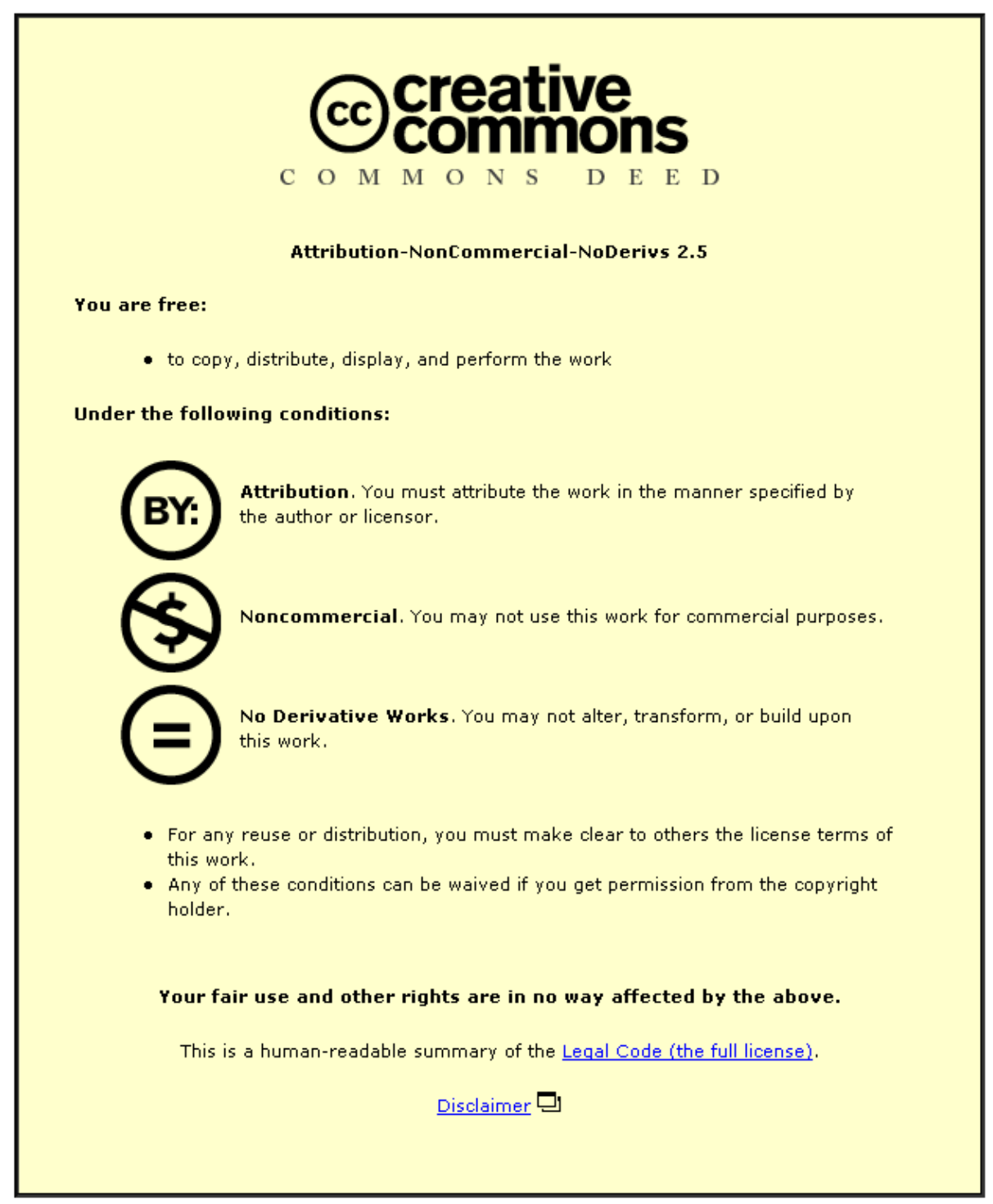

For the full text of this licence, please go to: http://creativecommons.org/licenses/by-nc-nd/2.5/ 


\title{
The Financing of Small Firms: \\ Different Continents, the Same Problems?
}

\author{
Grahame Boocock \\ Ismail Wahab
}

The importance of small firms for economic development has been recognised across the globe. Most governments are aware that smaller enterprises face problems not experienced by their larger counterparts, and have taken steps to provide financial assistance. This article compares the experiences of small firms in the United Kingdom and Malaysia, and assesses whether public and private sector financial initiatives in the two countries have reduced the existence of the "finance gap" thought to prevail in both countries. The research programme conducted for this article suggests that, despite differences in the financial infrastructures, the cultural backgrounds and stages of economic development, small firms in the UK and Malaysia seem to adopt the same financing practices and face the same difficulties in raising funds. The reasons for this phenomenon are explored and the implications for policy-makers are discussed.

It has been well documented and acknowledged that small firms form a large majority of the population of businesses in most developed and developing countries $^{1}$. The vast majority of UK firms, 99.2 percent of a total population of 3.7 million, employ fewer than 50 people and 2.5 million are sole traders (DTI, 1999). Small firms in the UK presently account for 38 percent of turnover and employ 44.7 percent of the private sector workforce. There are no equivalent figures for the contribution of small firms in Malaysia; however, such enterprises do represent the largest category of firms (around 84\%) in the manufacturing sector (Business Times 1996). 
Several academic studies have suggested that smaller enterprises play a critical role in assisting economic growth, improving the health of the economy, reducing unemployment, and promoting flexibility and innovation (e.g., Wilson, 1995; Storey, 1994). These findings make the case for government assistance on the grounds of direct economic benefits and positive "externalities" (Chittenden and Wildgust 1999). However, Curran (1999) emphasises that most small firms aim for survival and independence, rather than growth, while Gray (1998, p. 57) asserts that: "attitudes towards growth and the processes of growth itself are very complex."

For most businesses, growth is a positive and often necessary move for survival. Yet there are a number of potential drawbacks and problems associated with expansion. Growth usually requires capital and smaller firms often require larger amounts of finance, relative to their total value, than larger companies (Binks and Coyne 1983). It has often been suggested that the most commonly encountered obstacle to growth is raising the funds to support expansion plans (e.g., Bolton Committee 1971; Bank of England 1999; Chee 1986, 1992; Abdul Hamid and Abdul Rashid 1996).

The reasons why small firms experience problems in raising finance are based on market imperfections that stem from aysmmetries, particularly in the bank/small firm relationship. There is risk asymmetry between borrowers and lenders, whereby banks are unable to raise interest rates high enough to compensate for the perceived risk of failure of small firms, and information asymmetry, because the costs associated with the initial (and ongoing) appraisal of small firm advances are very high. One consequence of these asymmetries is "adverse selection". This phenomenon arises when lenders fail to adjust the interest rate for individual companies, but simply raise interest rates for the small firm sector as a whole. Asymmetries are also associated with the "moral hazard" problem, whereby ownermanagers (OMs) might be tempted to sanction expenditure on abnormal fringe benefits. To counter such problems, banks will typically call for collateral.

The financing practices (i.e., patterns and sources of external finance) and problems (i.e., existence of difficulties in raising finance) of growth-oriented small firms were 
examined in a research programme that gathered data from small firms in both the UK and Malaysia. The study attempted to answer these questions:

- Do the characteristics of small firms and their OMs differ between the UK and Malaysia?

- Do the requirements for external finance differ between small firms in the UK and Malaysia?

- Do the sources and patterns of finance used by small firms differ between the UK and Malaysia?

- Do the difficulties experienced by small firms in raising external finance differ between the UK and Malaysia?

The authors anticipated that financing practices and problems would diverge between the two countries because of differences in, for example: the level of economic development (Peterson and Shulman 1987); legal and/or fiscal precedents (Tamari 1980); or the financial infrastructure (Austin et al. 1993). It would be surprising to encounter no significant financing differences between the UK and Malaysia, despite the contrasting social, political, cultural and economic factors prevailing in the two countries.

\section{THE FINANCING OF SMALL FIRMS IN THE UK AND MALAYSIA}

Before addressing the above research questions, it is necessary to set out key developments in the financing of small firms in the two countries.

\section{The United Kingdom}

The Bolton Committee (1971), the Wilson Committee (1979) and numerous subsequent studies (including University of Cambridge 1992; Bank of England 1999) have reported that many small firms in the UK experience difficulties in raising longterm capital from external sources. The existence of finance "gaps" has persisted, despite the emergence of various forms of finance, both private and public, to assist 
the formation and expansion of small firms. The gaps are perceived to be especially prevalent for firms operating in the high-technology sphere.

Before the publication of "Bolton" (1971), a number of institutions had been set up by the government to help small businesses, but the impact of official initiatives was minimal. In the years since "Bolton", it has often been difficult to identify a coherent policy towards small firms. However, official policy has been largely based on the philosophy that "any intervention to promote small firms can be justified only if it is directed at the removal of, or compensation for, market imperfections" (Bannock and Albach 1991, p. 31).

Government support has concentrated on improving the provision of training, advice and consultancy rather than on direct assistance to firms (Boocock 1994). Where finance has been offered to small firms, government schemes have been designed to complement developments in private sector financial markets. Some initiatives that illustrate this point are given below.

Enterprise Investment Scheme (EIS). This initiative is a tax-based scheme to encourage individuals to invest directly into small firms (i.e., to act as "business angels"). The EIS succeeded the Business Expansion Scheme (BES). Under the BES, any investor not closely connected with the company could obtain tax relief on long-term, equity investments in new ordinary shares of qualifying unquoted companies. However, the BES failed to stimulate new venture creation in high-risk enterprises (Mason and Harrison 1994) and it was replaced by the EIS in 1994.

Under the EIS, companies can raise up to $£ 1$ million in equity per tax year. The scheme includes greater safeguards to prevent funds being channelled into taxavoidance vehicles. For many investors, however, the EIS is seen as somewhat bureaucratic and rather restrictive, with fiscal benefits being outweighed by the risks involved.

Small Firms Loan Guarantee Scheme (LGS). This initiative has been in operation since 1981. The LGS assists small firms to obtain debt finance. The rationale behind the scheme is: 
to facilitate the supply of finance to viable small firms where conventional loans are not available, possibly due to lack of security or track record, (and) to give lenders experience of lending to businesses which have a viable proposal but do not satisfy normal banking criteria (NERA 1990, p. 103).

Banks and other financial institutions are encouraged to provide finance up to a maximum of $£ 100,000$ for start-ups ( $£ 250,000$ for established firms where the risk is reduced). To counter the risk, the government guarantees 70 percent of any loan approved for new businesses ( 85 percent for established firms). The borrower pays interest on the loan plus a premium of 1.5 percent of the amount guaranteed. The Scheme provides "quasi-equity" loans and it "has reduced financial market imperfections by generating additional bank lending to viable projects, and a number of assisted firms have contributed significant economic additionality" (Boocock 1994, p. 64). Nonetheless, the finance available under the LGS has the effect of increasing a firm's gearing and it is expensive for the borrower. After a careful review of the LGS in 1999, £150m of the funds allocated to the Scheme by government were switched to a series of new venture capital funds to direct funds to high-technology-based firms.

This move confirmed that the UK government seems to be adopting a more interventionist approach to the financing of small firms. There are also moves towards a more competitive element in funding, a switch that has implications for the selection and targeting of growth-oriented firms. The new venture funds will back firms on the grounds of commercial rather than social criteria, even though previous attempts by official bodies to "pick winners" have tended to end in failure (Buckland and Davies 1995).

In the private sector, banks continue to be the most significant source of external finance for small firms in the UK (University of Cambridge 1992; Confederation of British Industry 1993; Bank of England 1999). The bank/small firm relationship came under strain in the 1980s. Overeager lenders confronted overeager borrowers and the consequences of the recession of the early 1990s were disastrous for all parties. Total borrowing by the small business sector has fallen steadily over recent years, 
from $£ 48 b n$ in 1991 to $£ 36 b n$ in 1998 (Boocock 1999). Action by the banks has enabled smaller firms to build more robust financial structures. Within the overall borrowing figures, the ratio of overdraft to term lending has fallen from 49:51 in 1992 to $30: 70$ in 1998.

There is also increasing evidence that small firms are making use of a wider range of funding options, including asset-based finance and venture capital (both institutional and via business angels). Bankers often act in a co-ordinating role, putting together appropriate financial packages in situations where traditional overdraft/term loan finance would not match the risk profile of a project. High-technology firms were cited above as a "problem area". Such firms typically incur heavy research and development costs then launch untested products in volatile markets. Banks have set up specialist units to assess proposals from such firms, and give appropriate advice on how to supplement conventional bank finance with risk capital.

Venture capital is provided by a range of financial institutions, including insurance companies, pension funds and banks. The amount invested by venture funds in UK companies has increased more than fourfold over the past decade, reaching nearly $£ 8 b n$ in 1999. Nonetheless, the contribution of the industry in overcoming barriers to growth in smaller firms has been described as "modest" (ACOST 1990). Generally, venture capitalists are reluctant to make investments of under $£ 250,000$, because of the "asymmetries" described above. Many of the larger investments have been in later-stage proposals or buy-outs.

As a consequence of the large-company focus of the formal venture funds, small firms often turn to informal investors for external equity (Mason and Harrison 1994; Coveney and Moore 1998).

Small firms that achieve a certain size require access to junior stock markets with less stringent listing requirements and lower issue costs. The Unlisted Securities Market and the Third Market encouraged firms to "go public" but met with limited success. Both markets are now closed. The Stock Exchange replaced them with the Alternative Investment Market (AIM) in June 1995. The creation of AIM enables small companies to raise new capital, and allows shareholders to trade their shares 
or simply to benefit from the enhanced reputation of being a publicly quoted company.

\section{Malaysia}

Before independence in 1957, the Malaysian economy was largely dependent upon the agricultural sector and the production of prime commodities such as tin and rubber. There were few manufacturing concerns. The contribution of smaller enterprises was not significant, and the majority of such firms were engaged in traditional sectors such as wood-carving, handicrafts and the production of batik garments. The nation has since experienced strong economic growth, transforming itself from a primarily commodity-producing country to a significant manufacturing centre.

In the late 1960s, the potential of the small firm sector was recognised in the First Malaysia Plan, 1MP (1966-1970). However, 1MP pointed out the financial difficulties faced by small firms (Malaysia 1966), without offering any solutions. Small firms were given increased support in the Second Malaysia Plan (1971-1975), although firms in rural areas were the main beneficiaries (Malaysia 1971). During this period, the New Economic Policy (NEP) was promulgated. The NEP's goal was to achieve national unity through poverty eradication. The redistribution of wealth through social engineering was its main emphasis.

The Government hoped to create a vibrant Bumiputera ${ }^{2}$ business community and 30 percent Bumiputera ownership of the corporate sector by 1990. The promotion and development of smaller enterprises (especially Bumiputera-owned) was a key part of the strategy to achieve this goal. The 2MP made loans valued at around RM800million $^{3}$ available to small firms over its five-year duration. The NEP's target of 30 percent Bumiputera ownership was not achieved, but the underlying philosophy of the NEP was retained in its successor, the National Development Policy.

Over the past decade, both 6MP (1991-95) and 7MP (1996-2000) have confirmed the availability of key support measures, notably fiscal incentives, and offered 
additional programmes to facilitate the expansion and modernisation of small- and medium-sized enterprises. Some of these programmes are briefly described below.

The Malaysian Government has established a number of funds, through the Central Bank, Bank Negara Malaysia (BNM). Such funds offer reasonable cost finance to rehabilitate ailing business and promote investment in priority sectors (Bank Negara Malaysia, various).

- $\quad$ The Enterprise Rehabilitation Fund (ERF) was set up to provide seed capital to Bumiputera entrepreneurs adversely affected by the economic recession of the mid-1980s. The ERF has operated ever since. It was instrumental in helping many firms through the recession of the late 1990s.

- $\quad$ The New Entrepreneurs Fund (NEF) was launched in 1989 to encourage Bumiputeras to establish businesses in manufacturing, agriculture, tourism and export-oriented industries. In line with most of the Funds described here, the NEF has been topped up on a number of occasions since it was first established.

- $\quad$ The Bumiputera Industrial Fund (BIF), also created in 1993, aims to stimulate the growth of small- and medium-sized enterprises (with at least $70 \%$ Bumiputera management and equity control), improving the design and quality of products, upgrading technology, and marketing products effectively.

All these long-established Funds offer finance at reasonable cost on generous repayment terms. For example, the BIF provides a maximum loan of RM2.5 million at an interest rate of 5 percent per year over a maximum period of eight years.

BNM acted decisively in the face of the economic difficulties of the late 1990s, with the launching of the Fund for Small and Medium Industries, and the Rehabilitation Fund for Small and Medium Industries. The desire to intervene in the market for finance remains strong. Apart from these BNM schemes channelled through commercial banks and financial institutions, other government agencies play an important role in promoting the growth of small firms. 
Perbadanan Usahawan Malaysia Berhad (PUNB) Venture Capital Fund. The PUNB Venture Capital Fund1 was launched in 1991, aimed at facilitating the entry of Bumiputera entrepreneurs into strategic industries and commerce. Entrepreneurs with viable projects are eligible to apply and are expected to contribute at least 20 percent of the total cost of the project. However, Boocock and Wahab (1997) found that PUNB beneficiaries were mainly furniture manufacturers, rather than the highrisk ventures normally associated with venture funding.

Majlis Amanah Rakyat (MARA) Loans. In line with the government's effort to create and develop a viable Bumiputera Commercial and Industrial Community $(\mathrm{BCIC})$, as outlined in the National Development Policy, MARA is actively involved in the formulation and management of Bumiputera industrial and commercial companies. Its loan division provides credit to small firms, for the purchase of fixed assets and for working capital needs.

Credit Guarantee Corporation (CGC). The CGC Malaysia Berhad was set up in 1972 to assist SMEs to gain access to institutional credit at reasonable cost. Its role is to bridge the gap that exists between SMEs and lenders through the provision of a guarantee system that is commercially viable over the long term. The guarantee system is principally aimed at assisting SMEs that have no collateral (or lack adequate collateral) to obtain the required institutional financing at reasonable cost. However, the overall effectiveness of CGC in meeting the needs of SMEs appears to have been somewhat limited (Boocock and Mohd Shariff 1995).

In summary, the Malaysian government has introduced a variety of agencies and schemes to promote the development of smaller enterprises. To strengthen and streamline institutional support, the Government recently rationalised 30 agencies under 13 ministries into five lead agencies. The Ministry of Finance will co-ordinate the finance facilities.

In the private sector, the extension of credit facilities to small firms by the commercial banks and finance companies has shown an increasing trend in recent years. The government had encouraged financial institutions to allocate a prescribed proportion 
of their loans to smaller enterprises, and the institutions were keen to comply. However, the upward trend in bank lending to small firms was halted in 1998. (At the time of the empirical research for this article, the economic recession of $1998 \mathrm{had}$ not yet taken hold.) The level of non-performing loans rose sharply, and the government implemented steps to remove such loans from the banks' portfolios. The Fund for Small and Medium Industries, and the Rehabilitation Fund for Small and Medium Industries were also established. Over the longer-term, the government is seeking to rationalise the banking system into a small number of well-capitalised institutions.

Besides the commercial banks and finance companies, a variety of governmentsponsored institutions extend credit facilities to small firms. They include the industrial finance institutions (mainly Malaysian Industrial Development Finance, Bank Pembangunan Malaysia Berhad, Bank Industri and the Sabah Development Bank), and the Federal Land Development Authority and rural credit institutions (mainly Bank Pertanian and Bank Rakyat).

Venture capital financing in Malaysia is still in its infancy. BNM encouraged banks and merchant banks to get directly involved in this industry as far back as the early 1980s, but official attempts to promote growth in the supply of venture funds have not been a success (Boocock 1995). Statistics for venture capital in Malaysia tend to be distorted by the inclusion of official funds (such as the PUNB Fund described above). On the demand side, impediments to growth include: a reluctance to dilute ownership, the relative ease of obtaining bank credit, and a general lack of awareness of the role of venture capitalists (Lin 1994; Bank Negara Malaysia, 1994, 1995).

To give small companies the opportunity to earn a public listing, the Kuala Lumpur Stock Exchange (KLSE) established a Second Board in 1988. After a decade, the number of companies quoted on the Second Board had reached 282, compared to 454 on the Main Board. The gap in the number of quoted companies on the two markets has closed substantially as smaller enterprises have become more aware of the equity market as an alternative source of funding. In addition, "strong economic fundamentals and corporate earnings enabled both stock markets to reach record levels of fund mobilisation and market capitalisation" (Boocock 1995, pp. 374-375). 
The authorities also recognised the need for capital in higher risk firms and an overthe-counter market was planned for 1997. However, logistical and economic problems meant that the launch of the Malaysian Exchange of Securities Dealing and Automated Quotation (MESDAQ) was delayed by more than 2 years. MESDAQ aims to attract high growth firms, especially those involved in technology based activities. The launching of MESDAQ gives venture funds an exit route for their investments, hence it could open up avenues for venture capital to play a more active role in financing the early stages of new and technology-based firms.

Progress in attracting companies to the new market has been modest. In terms of equity finance, therefore, the formal venture capital market has not really taken off, and the stuttering start by MESDAQ is unlikely to boost the availability of venture capital. On a more positive note, Boocock and Wahab (1997) observed that business angels do play an important role in providing risk finance to many smalland medium-sized enterprises in Malaysia.

\section{Comparison between UK and Malaysia}

Both countries appear, on the face of it, to be well provided with institutional sources of finance for small firms. Furthermore, the governments of both countries have introduced a range of policy initiatives, schemes and institutions to ensure that small firms have access to finance. The UK government's policy towards small firms remains largely based on the free market philosophy, with the aim of ensuring that competition between large and small firms is based on equality. Recent moves have been towards an interventionist approach, despite the fact that small firms in the UK have access to a greater number and range of private sector funding opportunities. The Malaysian government adopts a more proactive approach, underpinned by national programmes to ensure more participation by Bumiputeras in business activities. There is a critical difference in policy implementation. In Malaysia, the provision of finance at concessionary rates is considered an essential element of helping small firms, whereas the provision of soft loans in the UK is regarded as an unwarranted intrusion within the free-market economy. 
Despite the rapid expansion in the range of public and private sector financial initiatives, there is widespread perception that "finance" or "equity" gaps continue to exist in both countries (Boocock and Wahab 1997; University of Cambridge 1992). These gaps are perceived to present a major constraint to small firm growth in both countries (Chee 1986; ACOST 1990; Murray 1999), although the extent of any gaps is open to debate (DTI/Aston Business School 1991; Buckland and Davis 1995).

The findings of this article should add to this ongoing debate.

\section{THE EMPIRICAL RESEARCH}

This study was concerned with the financing of small manufacturing firms in both countries. The empirical research comprised a questionnaire survey administered in the UK and Malaysia, supplemented by in-depth interviews with a selection of firms in both countries. The interviews were used to generate valuable case studies. The criteria for inclusion in both parts of the research programme were that a firm had to be independently owned and employ fewer than 50 people.

The same questionnaire format was used in the UK and Malaysia. In the UK, a sample of small firms in the East Midlands region was selected at random from a commercial list supplied by Dun and Bradstreet (a major private-sector information source). The Malaysian sample was derived from lists obtained from the Ministry of International Trade and Industry and the Malaysian Entrepreneurship Development Centre.

As suggested by Sudman and Bradburn (1982), a booklet format questionnaire was used in order to achieve a good response. To determine the potential effectiveness of the research instrument, and to ensure that it met the objectives of the study, a pretest and pilot study of the questionnaire was conducted in both countries. A number of changes were incorporated to enhance return rates. A total of 1,000 and 520 questionnaires, respectively were sent in the UK and Malaysian surveys. One week after the initial posting, follow-up postcards were sent to nonrespondents. A total of 228 questionnaires (22.8\%) were returned and usable for analysis for the 
U.K. study and $112(22.0 \%)$ for the Malaysian study. These response rates compare favourably with similar studies conducted in this field (Boocock and Mohd Shariff 1996).

The questionnaire data facilitated quantitative analysis, but the case studies provide a rich source of qualitative data. Eight firms were interviewed in each country. In the context of this article, crucial information was gathered on growth orientation and the funding of past investment and future plans.

\section{RESULTS AND ANALYSIS}

This section uses the questionnaire data to compare the experience of small firms in the two countries, focusing on the small firm and OM characteristics, sources and patterns of finance, and difficulties in financing growth. The analysis concentrates on the questionnaire findings, but includes the qualitative data to illustrate key points.

\section{Characteristics of Small Firms and OMs}

A summary of the characteristics of small firms is shown in Exhibits 1 and 2.

Over half of the sample firms in the UK (64.1\%) and Malaysia (58.0\%) employ fewer than 20 employees and the largest category in both countries $(36.0 \%$ in the UK and $37.5 \%$ in Malaysia) employ fewer than 10 staff. The size profiles in the two countries are broadly similar, although firms in Malaysia do employ more in the three "above 20 " size bands - probably because wage costs are generally lower in Malaysia.

In terms of age, the highest frequency category in the UK (28.9\%) comprises firms that had been in operation for more than 20 years; by contrast, 28.7 percent of Malaysian firms had been in existence for between 5 and 9 years. More than half of the sample firms in Malaysia (55.6\%) are less than 10 years old, while such firms account for only 34.0 percent of the UK sample. Small manufacturing firms in Malaysia are clearly younger than their counterparts in the UK. This finding is not surprising because small firms have been a feature of the UK industrial and commercial landscape for much longer than in Malaysia. 
In both countries, small manufacturing firms make use of external advisers. However, Malaysian firms generally rely on relatives and friends $(42.9 \%)$ whereas the UK firms tend to turn to accountants $(71.1 \%)$ for financial advice. Accountants in Malaysia are generally linked with large firms and the preparation of financial statements for tax purposes. Banks are used regularly for advice by small firms in both countries. Chambers of commerce are consulted frequently in Malaysia $(17.0 \%)$, but they are rarely used in the UK.

Nearly 75 percent respondent firms in both countries are private limited companies. This legal form assists in fund raising, especially the ability to create collateral on company property.

Almost 40 percent of UK respondent firms are involved in fabricated metal products or textiles - great strengths of the East Midlands region. The three largest categories in Malaysia are wood and wood products, rubber and plastics, and food. The focus on natural resources is to be expected, and Malaysians love their food, much of which is provided by small firms. The majority of respondent firms in the UK $(62.7 \%)$ and Malaysia (71.4\%) could not, using a broad brush definition, be classed as "technology-based". 
Exhibit 1: Respondent Firm Characteristics

(Comparative Analysis)

\begin{tabular}{|c|c|c|}
\hline Characteristics & $\begin{array}{r}\text { United Kingdom } \\
(\text { Percent) } \\
(N=228)\end{array}$ & $\begin{array}{l}\text { Malaysia } \\
(\text { Percent }) \\
(N=112)\end{array}$ \\
\hline \multicolumn{3}{|l|}{ Employment Category } \\
\hline 1-9 employees & 36.0 & 37.5 \\
\hline 10-19 employees & 28.1 & 20.5 \\
\hline 20-29 employees & 11.4 & 12.5 \\
\hline 30-39 employees & 10.5 & 11.6 \\
\hline 40-49 employees & 14.0 & 17.9 \\
\hline Total & $\underline{100.0}$ & $\overline{100.0}$ \\
\hline \multicolumn{3}{|l|}{ Age of Firm } \\
\hline 4 years $\&$ below & 12.7 & 26.9 \\
\hline $5-9$ years & 21.3 & 28.7 \\
\hline $10-14$ years & 23.5 & 24.1 \\
\hline $15-19$ years & 13.6 & 8.3 \\
\hline 20 years and above & 28.9 & 12.0 \\
\hline Total & $\overline{100.0}$ & $\overline{100.0}$ \\
\hline \multicolumn{3}{|l|}{ Use of External Financial Adviser } \\
\hline Did not use external adviser & 22.8 & 26.8 \\
\hline Used external adviser & 77.2 & 73.2 \\
\hline Total & $\overline{100.0}$ & $\overline{100.0}$ \\
\hline \multicolumn{3}{|l|}{ Sources of Advice } \\
\hline Accountants & 71.1 & 25.9 \\
\hline Bankers & 41.4 & 40.2 \\
\hline Relatives/Friends & 11.5 & 42.9 \\
\hline Local Authority & 4.8 & 9.8 \\
\hline Chamber of Commerce & 0.4 & 17.0 \\
\hline \multicolumn{3}{|l|}{ Sector of Industry (i) } \\
\hline Fabricated Metal Product & 21.1 & 15.2 \\
\hline Textiles & 18.9 & 2.7 \\
\hline Publishing \& Printing & 8.8 & 2.7 \\
\hline Rubber \& Plastic Products & 6.6 & 11.6 \\
\hline Wood \& Wood Products & 6.6 & 25.0 \\
\hline Paper \& Paper Products & 4.4 & 2.7 \\
\hline Electrical Machinery & 4.4 & 1.8 \\
\hline Chemical \& Chemical Products & 3.5 & 2.7 \\
\hline Basic Metals & 2.6 & 5.4 \\
\hline Food Products \& Beverages & 1.7 & 12.5 \\
\hline Motor Vehicle \& Parts & 1.7 & 3.6 \\
\hline Other Manufacturing Industry & 19.7 & 14.1 \\
\hline Total & $\overline{100.0}$ & $\overline{100.0}$ \\
\hline (ii) Non Technology-based & 67.5 & 71.4 \\
\hline Technology-based & 32.5 & 28.6 \\
\hline Total & $\overline{100.0}$ & $\overline{100.0}$ \\
\hline \multicolumn{3}{|l|}{ Business Plan } \\
\hline Did not have a written business plan & 67.5 & 48.2 \\
\hline Had a written business plan & 32.5 & 51.8 \\
\hline Total & $\overline{100.0}$ & $\overline{100.0}$ \\
\hline
\end{tabular}




\section{Exhibit 2: Respondent Owner-Manager Characteristics}

(Comparative Analysis)

\begin{tabular}{|c|c|c|}
\hline Characteristics & $\begin{array}{r}\text { United Kingdom } \\
\text { (Percent) } \\
(N=228)\end{array}$ & $\begin{array}{l}\text { Malaysia } \\
\text { (Percent) } \\
(N=112) \\
\end{array}$ \\
\hline \multicolumn{3}{|l|}{ Age Group } \\
\hline 20-29 years & 1.8 & 15.2 \\
\hline $30-39$ years & 16.7 & 33.9 \\
\hline $40-49$ years & 38.1 & 28.6 \\
\hline $50-59$ years & 29.4 & 20.5 \\
\hline 60 years $\&$ above & 14.0 & 1.8 \\
\hline Total & 100.0 & 100.0 \\
\hline \multicolumn{3}{|l|}{ Training and Business Management } \\
\hline No training & 59.2 & 21.4 \\
\hline Some training & 40.8 & 78.6 \\
\hline Total & $\underline{100.0}$ & $\underline{100.0}$ \\
\hline \multicolumn{3}{|l|}{ Level of Education } \\
\hline Primary (and Secondary) Education & 35.5 & 16.1 \\
\hline Post-Secondary Education & 28.5 & 49.1 \\
\hline Degree or equivalent & 36.0 & 34.8 \\
\hline Total & 100.0 & 100.0 \\
\hline \multicolumn{3}{|l|}{ Level of Experience } \\
\hline No working experience & 9.2 & 21.4 \\
\hline 4 years \& below & 23.2 & 31.3 \\
\hline $5-9$ years & 26.8 & 26.8 \\
\hline $10-14$ years & 18.0 & 13.4 \\
\hline $15-19$ years & 9.2 & 5.4 \\
\hline 20 years \& above & 13.6 & 1.8 \\
\hline Total & 100.0 & 100.0 \\
\hline
\end{tabular}


Slightly more than half of firms in Malaysia (51.8\%) claim to have prepared business plans, whereas only 32.5 percent of respondents in the UK have produced such documents. The importance of business plans to support expansion has been widely acknowledged (Hannon and Atherton 1998). The OMs of sample firms in the UK, therefore, have still be convinced that it is worth giving up their valuable time for the preparation of plans. The lack of planning might also suggest that the firms have limited growth ambitions. The position in Malaysia appears to be more positive - assistance from government agencies in Malaysia is often linked to the production of a business plan. However, it is not clear how the plans are used.

Exhibit 2 reveals that the most frequent age category of the OMs in Malaysia is the 30-39 bracket (33.9\%), and almost half of OMs (49.1\%) are below 40 years old. In the UK, the age profile is significantly older, with the 40-49 years category accounting for 38.1 percent of the sample.

Marginally more OMs hold a degree or equivalent in the UK compared to Malaysia (36.0\% and 34.8\%, respectively). However, it is evident from Exhibit 2 that OMs in Malaysia tend to have been educated for longer at secondary/high school level. Many OMs in the UK left school as soon as possible. The comparison between the two countries with regard to business/management training is even more striking. Most Malaysian OMs (78.6\%) have undergone some form of training, whereas a majority of UK OMs (59.2\%) have chosen not to pursue such training.

Why should this differential in training be so strong? There is an ongoing debate in the UK about the value of business training (Westhead and Storey 1997; Cosh et al. 1998). The poor training opportunities could stem from a lack of awareness by OMs or "reservations about the ability of training to provide solutions to OMs' problems" (Mahmood 1993, p. 71). The OMs in Malaysia seem to accept the need for training more readily. The explanation for this phenomenon might lie in a lessquestioning culture in Malaysia (training is accepted as a 'good thing') or because training is often linked to the provision of official funding sources. 
Exhibit 2 also shows that Malaysian OMs are much less experienced than their UK counterparts. The majority of OMs in the UK $(67.6 \%)$ have more than 5 years work experience, with the equivalent figure for Malaysia being 47.4 percent. One would anticipate this finding, given the age profile of the OMs and firms in the respective national samples.

Overall, therefore, OMs in the UK are generally less well educated (both at school and for business training), and they spend less time on the production of business plans. However, they (and their firms) are generally older and, as a consequence, OMs in the UK have greater business experience.

\section{Need for External Finance}

Exhibit 3 confirms that the majority of small manufacturing firms in the UK $(61.0 \%)$ and Malaysia (78.6\%) approach external sources of finance to support business growth. To assess whether the need for external finance in both countries is significantly different, the chi-square test of independence was performed at the 5 percent significance level. The chi-square value of 10.49 implies there is a greater need for external finance in Malaysia.

\section{Exhibit 3: Need for External Finance}

(Comparative Analysis)

\begin{tabular}{|c|c|c|c|c|}
\hline \multirow{2}{*}{$\begin{array}{l}\text { External Finance } \\
\text { Did Not Approach External Finance } \\
\text { Approached External Finance }\end{array}$} & \multicolumn{2}{|c|}{$\begin{array}{l}\text { United } \\
\text { Kingdom }\end{array}$} & \multicolumn{2}{|c|}{ Malaysia } \\
\hline & $\begin{array}{r}89 \\
139 \\
\end{array}$ & $\begin{array}{l}(39.0 \%) \\
(61.0 \%) \\
\end{array}$ & $\begin{array}{l}24 \\
88 \\
\end{array}$ & $\begin{array}{l}(21.4 \%) \\
(78.6 \%) \\
\end{array}$ \\
\hline Total & 228 & $(61.0 \%)$ & 112 & $(100 \%)$ \\
\hline $\begin{array}{l}x^{2} 10.49 \\
d f 1, p 0.001\end{array}$ & & & & \\
\hline
\end{tabular}

The most frequently cited reason for applying for external finance in Exhibit 4 (overleaf) is to increase sales and/or share within existing markets (UK, 71.2\%; Malaysia, 69.2\%). This demand for finance could be for short-term, working 
capital needs, or to satisfy longer-term requirements for investment in (say) enhanced production facilities. The need for Malaysian firms to sell existing products in new markets (whether at home or overseas) is evident. This is not surprising, given the limited domestic market facing Malaysian small firms.

\section{Exhibit 4: Reasons for Applying for External Finance}

(Comparative Analysis)

\begin{tabular}{|lrr|}
\hline Reasons & $\begin{array}{r}\text { UK } \\
\text { (Percent) } \\
(N=139)\end{array}$ & $\begin{array}{r}\text { Malaysia } \\
\text { (Percent) } \\
(N=88)\end{array}$ \\
\hline & & \\
To increase sales/share of existing market & 71.2 & 69.3 \\
To introduce new products to existing markets & 16.5 & 13.6 \\
To enter new markets with existing products & 15.8 & 60.2 \\
To expand overseas & 7.9 & 22.7 \\
To acquire another firm & 5.8 & 4.5 \\
\hline
\end{tabular}

In line with expectations, only a small number of firms in the U.K. and Malaysia (5.8\% and $4.5 \%$, respectively) sought external finance for acquisition purposes.

The need for external finance was explored in the 16 case studies. The literature suggests that growth-orientation of the firm will be strongly associated with the need for additional funding. The case study firms were divided into three categories of growth - fast, steady and "none" - in terms of past performance and future growth intentions (see Exhibit 5). Growth was considered in a number of dimensions, including sales and profits, but principally whether the firms had conducted (or intended to conduct) product/process innovation or undertaken (or planned to undertake) investment. The case studies confirm that growth-oriented firms do require additional finance. However, the evidence as to whether case study firms in Malaysia have a greater need for external finance was inconclusive.

\section{Sources of External Finance}

Exhibit 6 demonstrates that small manufacturing firms in either Malaysia or the UK make little use of external equity finance. The vast majority of small firms prefer to use internal equity, particularly personal savings (Md. Salleh 1990; Levy, 1993) 
and retained profits (Oakey et al. 1991). Where external equity is sought, small firms in both countries generally turn to relatives and friends as a first resort, 13.0 percent and 13.6 percent in the UK and Malaysia, respectively. Business angels in both countries tend to be associated with investee firms beforehand, although investors in some UK firms had utilised the BES Scheme or EIS (7.9\%).

A greater number of firms in the UK (12.2\%) use formal venture capital, compared to a mere two firms in Malaysia (2.3\%). Firms in Malaysia (8.0\%) also take advantage of the government-backed PUNB scheme (it was suggested above that this could not be classed as genuine venture funding). The low utilisation of venture funding in Malaysia is not unexpected, given the state of development of the sector, and the reasons outlined above (e.g., the reluctance to dilute ownership for fear of losing control).

Turning to debt finance, Exhibit 6 confirms the overall importance of banks as the principal providers of external debt. Small firms in both countries rely heavily on short- and medium-term debt finance. Nevertheless, overdraft finance remains the most widely used source by firms in Malaysia (58\%) and in the UK (79.1\%). This pattern confirms previous studies (including Stanworth and Gray 1991; Austin et al. 1993). While overdraft finance can offer flexibility at lower cost, it can also be associated with poor business planning and a lack of financial control (Confederation of British Industry, 1993). Some firms in both countries appear to have used overdraft finance to fund the purchase of fixed assets or other longterm requirements.

More firms in Malaysia have taken out short-term loans (39.8\% compared to $32.4 \%$ in the UK). More UK firms have access to longer-term loans; this confirms the recent trend towards longer-term funding in the UK (Bank of England 1999), but the trend is certainly not pronounced in the data in Exhibit 6 . If the study were to be repeated in the year 2000 , the proportion of loans in the "over 5-year" category would probably be much higher. 
Exhibit 5: Summary of Case Studies

\begin{tabular}{|c|c|c|c|c|c|c|c|}
\hline \multicolumn{8}{|c|}{ United Kingdom } \\
\hline \multirow[t]{2}{*}{ Firm } & \multirow{2}{*}{$\begin{array}{l}\text { Products } \\
\text { Manufactured }\end{array}$} & \multirow{2}{*}{$\begin{array}{l}\text { Past } \\
\text { Growth }\end{array}$} & \multirow{2}{*}{$\begin{array}{l}\text { Growth } \\
\text { Potential }\end{array}$} & \multirow{2}{*}{$\begin{array}{l}\text { Sources of } \\
\text { Internal Finance }\end{array}$} & \multicolumn{2}{|c|}{ Sources of External Finance } & \multirow{2}{*}{$\begin{array}{l}\text { Financing } \\
\text { Difficulties }\end{array}$} \\
\hline & & & & & Equity & Debt & \\
\hline A & Textiles & Steady & Steady & $\begin{array}{l}\text { Retained profits } \\
\text { Personal savings }\end{array}$ & None & $\begin{array}{l}\text { Bank overdraft } \\
\text { Bank term loan } \\
\text { Hire purchase } \\
\text { Leasing }\end{array}$ & No difficulty \\
\hline$B$ & Leather & Steady & Steady & Retained profits & None & $\begin{array}{l}\text { Bank overdraft } \\
\text { Bank term loan }\end{array}$ & No difficulty \\
\hline $\mathrm{C}$ & $\begin{array}{l}\text { Medical } \\
\text { Equipment }\end{array}$ & Rapid & Steady & $\begin{array}{l}\text { Retained profits } \\
\text { Director's loan }\end{array}$ & None & $\begin{array}{l}\text { Bank overdraft } \\
\text { Hire purchase }\end{array}$ & $\begin{array}{l}\text { Unreasonable } \\
\text { security/ } \\
\text { collateral }\end{array}$ \\
\hline $\mathrm{D}$ & Textiles & Rapid & $\begin{array}{l}\text { No } \\
\text { growth }\end{array}$ & Retained profits & None & $\begin{array}{l}\text { Bank overdraft } \\
\text { Bank term loan } \\
\text { Hire purchase }\end{array}$ & No difficulty \\
\hline$E$ & Publishing & Steady & Steady & Retained profits & None & Leasing & $\begin{array}{l}\text { Insufficient } \\
\text { finance } \\
\text { available }\end{array}$ \\
\hline $\mathrm{F}$ & $\begin{array}{l}\text { Machine } \\
\text { Tools }\end{array}$ & Rapid & Rapid & Retained profits & None & $\begin{array}{l}\text { Bank overdraft } \\
\text { Bank term loan } \\
\text { Government- } \\
\text { backed (LGS) } \\
\text { British Coal } \\
\text { Hire purchase }\end{array}$ & $\begin{array}{l}\text { Unreasonable } \\
\text { security/ } \\
\text { collateral }\end{array}$ \\
\hline G & Rubber & Rapid & Rapid & Retained profits & $\begin{array}{l}\text { Government- } \\
\text { backed } \\
\text { (BES) } \\
\text { Relatives }\end{array}$ & $\begin{array}{l}\text { Bank overdraft } \\
\text { Bank term loan } \\
\text { Hire purchase } \\
\text { Leasing }\end{array}$ & $\begin{array}{l}\text { Lack of } \\
\text { collateral, } \\
\text { high interest } \\
\text { rate \& } \\
\text { insufficient } \\
\text { finance } \\
\text { available }\end{array}$ \\
\hline $\mathrm{H}$ & $\begin{array}{l}\text { Industrial } \\
\text { Design }\end{array}$ & Steady & $\begin{array}{l}\text { No } \\
\text { growth }\end{array}$ & $\begin{array}{l}\text { Retained profits } \\
\text { Personal savings } \\
\text { Director's loan }\end{array}$ & None & $\begin{array}{l}\text { Bank overdraft } \\
\text { Trade Credit } \\
\text { Hire purchase }\end{array}$ & No difficulty \\
\hline
\end{tabular}




\section{Exhibit 5: Summary of Case Studies (continued)}

\begin{tabular}{|c|c|c|c|c|c|c|c|}
\hline \multicolumn{8}{|c|}{ Malaysia } \\
\hline \multirow[t]{2}{*}{ Firm } & \multirow{2}{*}{$\begin{array}{l}\text { Products } \\
\text { Manufactured }\end{array}$} & \multirow{2}{*}{$\begin{array}{l}\text { Past } \\
\text { Growth }\end{array}$} & \multirow{2}{*}{$\begin{array}{l}\text { Growth } \\
\text { Potential }\end{array}$} & \multirow{2}{*}{$\begin{array}{l}\text { Sources of } \\
\text { Internal Finance }\end{array}$} & \multicolumn{2}{|c|}{ Sources of External Finance } & \multirow{2}{*}{$\begin{array}{l}\text { Financing } \\
\text { Difficulties }\end{array}$} \\
\hline & & & & & Equity & Debt & \\
\hline I & Chemicals & Rapid & Rapid & Director's loan & None & $\begin{array}{l}\text { Bank overdraft } \\
\text { Bank term loan } \\
\text { Hire purchase }\end{array}$ & $\begin{array}{l}\text { Insufficient } \\
\text { finance } \\
\text { available \& } \\
\text { high interest } \\
\text { rate }\end{array}$ \\
\hline $\mathrm{J}$ & Wire & Rapid & Rapid & Retained profits & None & $\begin{array}{l}\text { Relatives } \\
\text { Government- } \\
\text { backed (ITAF) } \\
\text { Bank term loan } \\
\text { Leasing }\end{array}$ & $\begin{array}{l}\text { Insufficient } \\
\text { finance } \\
\text { available }\end{array}$ \\
\hline K & $\begin{array}{l}\text { Fabricated } \\
\text { Steel }\end{array}$ & Steady & Steady & $\begin{array}{l}\text { Retained profits } \\
\text { Personal savings }\end{array}$ & Relatives & $\begin{array}{l}\text { Trade credit } \\
\text { Hire purchase }\end{array}$ & $\begin{array}{l}\text { Insufficient } \\
\text { finance } \\
\text { available }\end{array}$ \\
\hline $\mathrm{L}$ & Leather & Steady & Steady & $\begin{array}{l}\text { Retained profits } \\
\text { Personal savings }\end{array}$ & None & $\begin{array}{l}\text { Bank overdraft } \\
\text { Bank term loan } \\
\text { Government- } \\
\text { backed (ERF) }\end{array}$ & No difficulty \\
\hline $\bar{M}$ & $\begin{array}{l}\text { Electronic } \\
\text { Components }\end{array}$ & Rapid & $\begin{array}{l}\text { No } \\
\text { growth }\end{array}$ & $\begin{array}{l}\text { Retained profits } \\
\text { Personal savings }\end{array}$ & None & $\begin{array}{l}\text { Bank term loan } \\
\text { Hire purchase }\end{array}$ & No difficulty \\
\hline $\mathrm{N}$ & $\begin{array}{l}\text { Staples/ } \\
\text { Paper clips }\end{array}$ & Steady & Rapid & Retained profits & None & $\begin{array}{l}\text { Bank overdraft } \\
\text { Bank term loan } \\
\text { Hire purchase } \\
\text { Leasing }\end{array}$ & $\begin{array}{l}\text { High interest } \\
\text { rate \& lack of } \\
\text { collateral }\end{array}$ \\
\hline $\mathrm{O}$ & Plastics & Rapid & Rapid & Retained profits & $\begin{array}{l}\text { Government- } \\
\text { backed } \\
\text { (PUNB) }\end{array}$ & $\begin{array}{l}\text { Bank overdraft } \\
\text { Bank term loan } \\
\text { Hire purchase } \\
\text { Trade credit } \\
\text { Government- } \\
\text { backed (CGC } \\
\text { \& ITAF) }\end{array}$ & No difficulty \\
\hline $\mathrm{P}$ & Plastics & Steady & $\begin{array}{l}\text { No } \\
\text { growth }\end{array}$ & $\begin{array}{l}\text { Retained profits } \\
\text { Personal savings }\end{array}$ & None & $\begin{array}{l}\text { Bank overdraft } \\
\text { Bank term loan } \\
\text { Hire purchase } \\
\text { Trade credit }\end{array}$ & No difficulty \\
\hline
\end{tabular}


Besides bank finance, other non-bank sources are also used, especially hirepurchase and trade credit in Malaysia and leasing in the UK. Government-backed loan schemes are more widely used in Malaysia, although utilisation is relatively modest in both countries.

The case studies amplify key aspects of the questionnaire findings. In the UK and Malaysia, firms with rapid growth performance or potential were more likely to make use of government-backed schemes. With regard to external equity funding, this finding has to be tempered with caution. No firms had used formal venture capital, and only one firm in each country had utilised the BES (UK) and PUNB (Malaysia) - both of these schemes allow the recipient to retain more equity than private sector risk capital. Fast-growth firms also have greater utilization of bank overdrafts and term loans, as well as hire purchase and leasing. Irrespective of the growth orientation of the case study firms, the financial structures were generally consistent with the "pecking order hypothesis" - internal debt and equity is preferred to external debt, with external equity considered as a last resort (Cosh and Hughes 1994; Myers and Majluf 1984).

Overall, the questionnaire and case study data suggest the sources of finance used by small firms in the two countries are broadly similar.

\section{Financing Patterns}

Although it was not possible to ascertain the precise composition of external equity and debt within financing packages - the information was too sensitive to explore in the questionnaire or even in the interviews for the case studies - Exhibit 7 summarizes the questionnaire responses.

The majority of questionnaire respondents in Malaysia (76.1\%) and the UK $(69.8 \%)$ do not use external equity. Where external equity is used, firms in both countries tend to rely on a single source. Only 2.3 percent and 4.3 percent, respectively, of sample firms in Malaysia and the UK utilize more than one source of external equity. The pattern of debt finance is quite different, with multiple sources of debt being much more prominent. Only a small percentage of 
Malaysian and UK firms (2.3\% and $0.7 \%$, respectively) do not have some form of debt finance.

To assess whether the pattern of external finance used by respondent firms in the two countries is significantly different, the chi-square test was again executed. (The "one source" and "two source" categories of equity finance were combined to avoid the problem of small expected frequencies: Siegel and Castellan 1988). The chi-square values shown in Exhibit 7, 1.08 for equity and 8.70 for debt, are not significant at the 5 percent level.

It is difficult to draw any definite conclusions, given the lack of data on the proportion of debt/equity financing used to fund expansion. However, the findings do not point to any significant differences in the pattern of external finance by small firms used in Malaysia and the UK.

\section{Difficulties in Raising External Finance}

Whilst the majority of small manufacturing firms in Malaysia (80.7\%) and in the UK (84.9\%) had succeeded in a recent application for external finance (Exhibit 8), a greater percentage of Malaysian than UK firms (49.3\% compared to $44.1 \%$ ) had encountered some difficulties (Exhibit 9). The chi-square values shown in Exhibits 8 and 9 are not significant, implying that the incidence of financing difficulties is independent of the two countries.

Exhibit 10 offers more meaningful data. The main financing difficulties, as anticipated, relate to the availability of sufficient finance (usually linked to a lack of collateral) and high interest rates (Chee 1986; Binks et al. 1986; and Stanworth and Gray 1991). These factors combine to create "financing difficulties" - an outright failure to obtain the required funding, or perhaps being offered insufficient finance at higher than anticipated interest rates. The duration of loans was also one of the major obstacles facing Malaysian firms. 
Exhibit 6: Sources of External Finance

(Comparative Analysis)

\begin{tabular}{|lrr|}
\hline Sources & $\begin{array}{r}\text { United Kingdom } \\
\text { (Percent) } \\
(N=139)\end{array}$ & $\begin{array}{r}\text { Malaysia } \\
\text { (Percent) } \\
(N=88)\end{array}$ \\
\hline Equity & 12.2 & 2.3 \\
Venture Capital & 7.9 & 8.0 \\
Government-backed Scheme & 13.0 & 13.6 \\
Relatives/Friends & & \\
& & 58.0 \\
Debt & 79.1 & 39.8 \\
Bank Overdraft & 32.4 & 15.9 \\
Bank Loan (<5 years) & 18.7 & 43.2 \\
Bank Loan (>5 years) & 26.6 & 14.8 \\
Trade Credit & 6.5 & 51.1 \\
Government-backed Scheme & 46.0 & 19.3 \\
Hire-Purchase & 29.0 & 2.3 \\
Leasing & 7.9 & \\
Factoring & & \\
\hline
\end{tabular}


Exhibit 7: Patterns of External Finance

(Comparative Analysis)

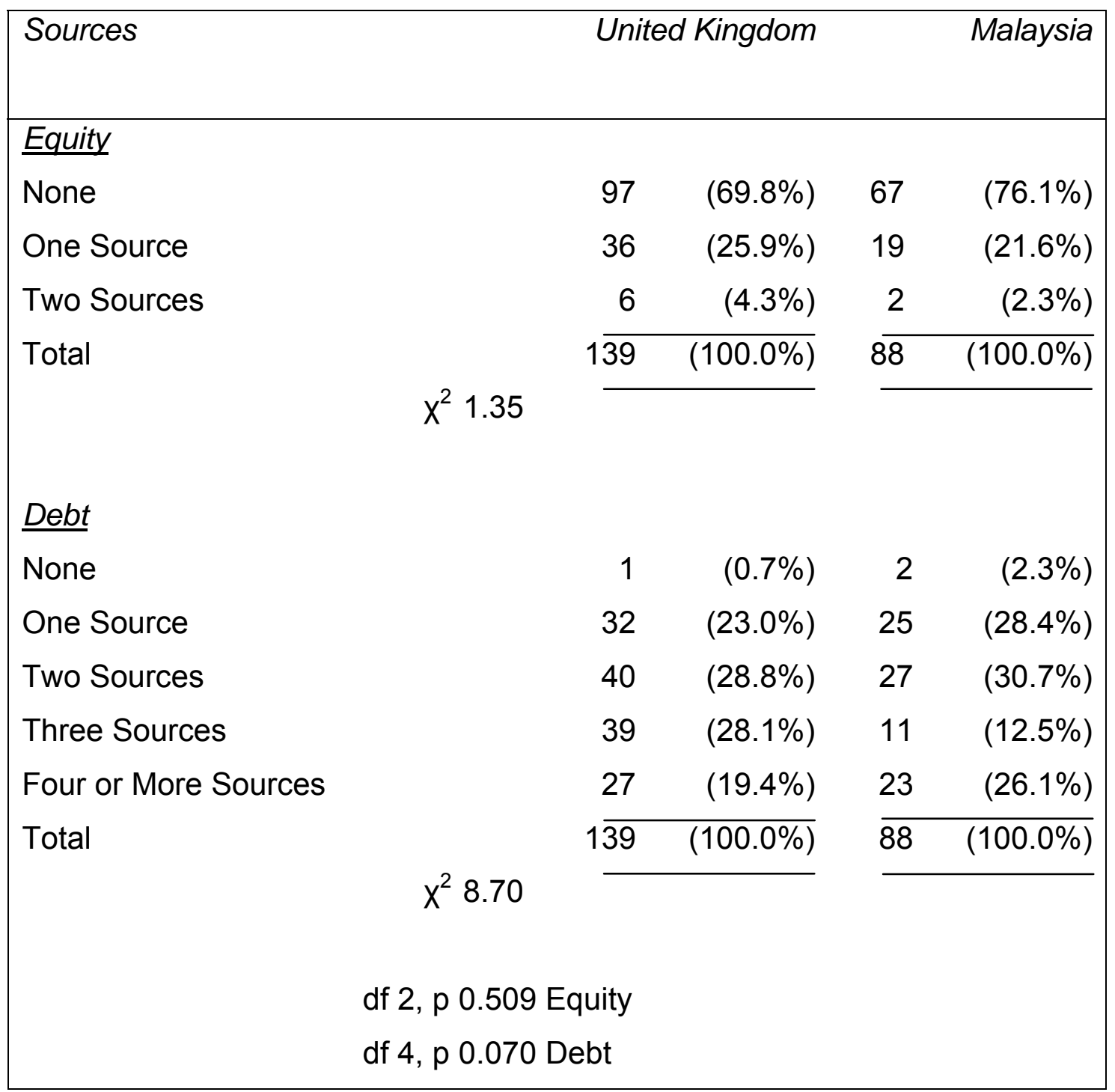


Exhibit 8: Status of Recent Application for External Finance

(Comparative Analysis)

\begin{tabular}{|c|c|c|c|}
\hline Status & United Kingdom & & Malaysia \\
\hline Not Successful & $21 \quad(15.1 \%)$ & 17 & $(19.3 \%)$ \\
\hline Successful & $118 \quad(84.9 \%)$ & 71 & $(80.7 \%)$ \\
\hline Total & $139 \quad(100.0 \%)$ & 88 & $(100.0 \%)$ \\
\hline $\begin{array}{r}x^{2} 0.69 \\
\text { df } 1, p 0.408\end{array}$ & & & \\
\hline
\end{tabular}

Exhibit 9: Existence of Difficulties in Obtaining External Finance (Comparative Analysis)

\begin{tabular}{|c|c|c|c|}
\hline Existence of Difficulties & & United Kingdom & Malaysia \\
\hline No Difficulty & & $66 \quad(55.9 \%)$ & $36 \quad(50.7 \%)$ \\
\hline \multirow[t]{4}{*}{ Some Difficulties } & & $52 \quad(44.1 \%)$ & $35 \quad(49.3 \%)$ \\
\hline & Total & $118(100.0 \%)$ & $71(100.0 \%)$ \\
\hline & $x^{2} 0.49$ & & \\
\hline & of $1, p 0.485$ & & \\
\hline
\end{tabular}




\section{Exhibit 10: Types of Difficulties in Obtaining External Finance}

(Comparative Analysis)

\begin{tabular}{|lcc|}
\hline Types of Difficulties & $\begin{array}{c}\text { United Kingdom } \\
\text { (Mean) } \\
(N=52)\end{array}$ & $\begin{array}{c}\text { Malaysia } \\
\text { (Mean) } \\
(N=35)\end{array}$ \\
\hline Insufficient amount of finance & 4.14 & 3.75 \\
Unreasonable level of collateral & 3.98 & 3.26 \\
High interest rate & 3.87 & 3.29 \\
Duration of loan offered was too short & 2.65 & 3.37 \\
The mean scores for the variables rest on a five-point Likert-type scale, \\
with "1" denoting strongly disagree and "5" strongly agree on the variables.
\end{tabular}

The case studies confirm that growth-oriented firms tend to suffer more difficulties in raising finance than (say) lifestyle businesses. This phenomenon applies in both countries. The analysis should not suggest, however, that all reasonable funding propositions were refused. The researchers only heard the entrepreneurs' side of the story. Small firms will always seek more finance at a lower cost and with fewer strings attached. Innovation is risky, especially where younger firms are involved. Fast growth firms frequently seek to develop new products for which demand is uncertain. Bankers and other financiers have to make decisions on commercial viability. Furthermore, the presentation of proposals may have been weak.

Overall, however, this research programme could not isolate significant differences in the financing difficulties between the two countries. 


\section{DISCUSSION AND RECOMMENDATIONS}

This article compared the experiences of small manufacturing firms in the UK and Malaysia, focusing on small firm and OM characteristics, sources and patterns of finance, and difficulties in financing growth. The questionnaire data revealed no significant differences between small firms in the two countries with regard to legal status, type of industry and size of the firms. There are, however, some marked differences relating to age of firms and OMs; use of external advisers; existence of business plans; and level of education, training and experience of OMs. These factors exert some influence on the need for external finance between the two countries, but wider economic, social and cultural factors appear to have a stronger effect on the sources/patterns of finance and the difficulties experienced in fund raising.

There is a significant difference between the two countries with regard to the need for external finance by small manufacturing firms. This striking difference can perhaps be explained by the different stages of economic development between the UK and Malaysia. The later industrialisation of Malaysia means that sample firms are generally newer, with a smaller base of retained profits to use as a springboard for fund raising. The continuing dependence of the economy on commodities such as wood and rubber means that firms might be trying to move into other areas, requiring finance to support investment plans.

The difference in the need for external finance could also stem from the differing levels of sophistication in the financial infrastructures in the UK and Malaysia. The UK has a well-developed financial spectrum, largely deregulated and making use of advanced credit appraisal techniques. It is generally acknowledged that equity and finance gaps have narrowed over the years, although there will always be firms at the margin of the risk/return frontier that feel they are denied legitimate access to requests for funds. However, there is little reason to suppose that a liberalized financial market will not offer competitive products, rates and terms to firms that wish to avail themselves of support (Buckland and Davis 1995, p.277). 
The banking industry in Malaysia is dominated by a small number of domestic institutions controlled by the federal government or quasi-governmental entities. The government has a majority stake in the three largest domestic banks, and there are important restrictions on the operations of foreign banks that do not apply to domestic banks. The financial sector is underpinned by close relationships between large corporations, banks and government - there is a strong commitment by multiple stakeholders to the survival and growth of corporations. Accounting principles are opaque, and a lack of accountability creates opportunities for the asymmetries described above and moral hazard. This situation is exacerbated by cultural differences; the ethos in Malaysia is "collective" rather than "individualistic" (Hofstede 1980). In such an environment, there is less emphasis on objective rationality and more reliance on factors such as the character and contacts of borrowers. These factors have resulted in some ill-advised investments within bank portfolios.

The focus on large corporations has led to the imposition of lending guidelines requiring that banks assist Bumiputeras and smaller enterprises. These guidelines apply to all banks, foreign and domestic alike (OECD 1999a). There is no doubt that an interventionist approach has played a critical role in promoting the growth of Bumiputera entrepreneurs and smaller enterprises, yet these interventions have distorted the financial markets. The empirical research suggests that some credit rationing was taking place before the onset of the recession in 1998. The onset of the recession led to a marked deterioration in private-sector funding opportunities available to small firms.

The short-term moves by the authorities in Malaysia to clean up the bank portfolios and generate more lending capacity were timely and necessary. The recent drive to rationalize the banking industry is perhaps more questionable. Over the longer term, a market-led adjustment and deregulation (and an injection of foreign expertise) might bring greater benefits (OECD 1999b). For example, credit appraisal techniques would improve and risk could be priced accordingly.

Turning to the sources/patterns of external finance and the difficulties experienced in raising external finance, there were no statistically significant differences between the UK and Malaysia. 
However, there was some evidence that government-sponsored institutions were displacing private sector finance in Malaysia. This would reinforce the argument that deregulation is the way forward, leaving the Government to concentrate its efforts on providing truly additional finance. Another interesting finding was the reliance in Malaysia on short-term bank loans. Access to longer-term funds gives a greater degree of certainty and permits longer-term financial planning.

With regard to the difficulties experienced in raising funds, it is impossible to draw any firm conclusions. The main complaints relate to the availability of sufficient finance (usually linked to a lack of collateral) and high interest rates, leading to a failure to obtain the required funding, or perhaps being offered insufficient finance at higher than anticipated interest rates. Potential high-growth firms probably have to contend with suboptimal financing structures and there is heavy reliance on shortterm debt finance.

Entrepreneurs in both countries have to be persuaded of the benefits of equity finance - a programme of education is required. (The prevalence of business plans in Malaysia does not seem to have led to more sophisticated financial planning.) On the supply side, it is significant the UK authorities have chosen to switch some of the funding allocated to the Loan Guarantee Scheme to venture funds aimed at high technology companies. The positive externalities stemming from high tech companies need to be captured for the benefit of the wider economy. Bankers and venture capitalists have to be convinced of the value of high-risk investments with an uncertain payback. The hope in the UK is that public-sector intervention will demonstrate that commercial returns are available, and hence increase the supply of risk capital. However, the Malaysian experience illustrates some of the issues associated with targeting small firms for public sector support. 


\section{Notes}

1. In the UK, the latest Department of Trade and Industry definition of a small firm refers to an enterprise having fewer than 50 employees. Small-scale industries in Malaysia are defined as manufacturing establishments employing between 5 and 50 full-time workers.

2. The term Bumiputera means "son of the soil". Although usually used in reference to the Malays, the term also encompasses other indigenous communities in the country.

3. $\mathrm{RM}=$ Malaysian Ringgit. Over the period of this study, the rate of exchange was approximately RM4 $=£ 1$.

\section{References}

Abdul Hamid, S., and Rashid Z. Abdul. 1996. Government assistance programmes for small and medium scale enterprises and linkage analysis. The Small and Medium Enterprise Workshop, organised by Faculty of Economics and Management, UPM (unpublished).

ACOST, 1990. The enterprise challenge: Overcoming barriers to Growth in small firms. London: HMSO.

Austin, S., A. Berry, S. Faulkner, M. Hughes, and J. Johnson. 1993. Finance, new technology and SMEs: A comparative study of U.K. and France. Working paper (unpublished), 16th National Small Firms Policy and Research Conference, Nottingham University.

Bank Negara Malaysia. Various. Annual Reports. Kuala Lumpur.

Bank of England. 1999. The financing of small firms. Quarterly Bulletin. May. 
Bannock, Graham and Horst Albach. 1991. Small business policy in Europe. Anglo-German Foundation for the Study of Industrial Society.

Binks, Martin and John Coyne. 1983. The birth of enterprise: An analytical and empirical study of the growth of small firms. London: The Institute of Economic Affairs.

Binks, M., A. Jennings, and P. Vale. 1986. Tripartite funding and the constriction of enterprise. In Faulkner, T, G. Beaver, J. Lewis and A. Gibb, eds., Readings in small business. Gower: 1-26.

Bolton Committee. 1971. Report of the committee of inquiry on small firms. London: Cmnd. 4811, HMSO.

Boocock, G. 1999. Learning to live together. Financial World (August) London: CIOB.

Boocock, Grahame. 1994. External funding for small firms: An assessment of the Credit Guarantee Corporation in Malaysia and The Loan Guarantee Scheme in the United Kingdom, Journal of International Business and Entrepreneurship 3, 1 and 2: pp.45-68.

Boocock, Grahame. 1995. Venture capital in Malaysia: The role of the government. Development Policy Review 13, 4: pp.371-390.

Boocock, G. and M. N. Mohd Shariff. 1995. Government-backed loan guarantee schemes for small and medium-sized enterprises: An evaluation of the Credit Guarantee Corporation in Malaysia. Research Paper No.94/ 95. Loughborough University Banking Centre.

Boocock, J.G. and M.N. Mohd Shariff. 1996). Loan guarantee schemes for SMEs The experience of Malaysia. Small Enterprise Development 7, 2:.25-36. 
Boocock, J.G. and I.A. Wahab. 1997. The financing practices and problems of growth-oriented small firms in Malaysia. Journal of International Business \& Entrepreneurship 5, 2: 1-28.

Buckland, R. and E.W. Davis. 1995. Finance for Growing Enterprises. London: Routledge.

Chee Peng Lim. 1986. Study and evaluation of existing fiscal and financial policies and supports for small and medium businesses in Malaysia. In James, K, and N. Akrasanee, eds., Small and medium business improvement in the ASEAN region: financial factors. Singapore: ISEAS: pp.57-104.

Chee Peng Lim. 1992. Potential and problems of SMI. In Kim Seung Jin and Suh Jang-Won, eds., Co-operation in small and medium-scale industries in ASEAN. Kuala Lumpur: Asian and Pacific Development Centre: pp.29-51.

Chittenden, F. and S. Wildgust. 1999. The small business service: A commentary. Unpublished Paper, ISBA Policy Forum, October 11.

Confederation of British Industry. 1993. Finance for growth: Meeting the financing needs of small and medium enterprises. Report of CBI Smaller Firms Council. London.

Cosh, A. and A. Hughes. 1994. Size, financial structure and profitability: UK Companies in the 1980s. In Hughes and D.J. Storey, eds., Finance and the small firm. London: Routledge: 18-63.

Cosh, A., J. Duncan, and A. Hughes. 1998. Investment in training and small firm growth and survival: An empirical analysis for the UK 1987-95. DfEE Research Report No. 36. London: HMSO.

Coveney, Patrick, and Karl Moore. 1998. Business angels. UK: John Wiley \& Sons. 
Curran, J. 1999. A response to the DTI consultancy paper on the new small business service. Unpublished Paper. ISBA Policy Forum. October 11.

DTI/Aston Business School. 1991. A report of a survey of small firms. Constraints on the Growth of Small Firms. London: Department of Trade and Industry, HMSO.

DTI. 1999. Statistical Bulletin (August). London: Department of Trade and Industry, HMSO.

Gray, C. 1998. Enterprise and Culture. London: Routledge.

Hannon P. D. and A. Atherton. 1998. Small firm success and the art of orienteering: The value of plans, planning and strategic awareness in the competition small firm. Journal of Small Business and Enterprise Development 5, 2:102-119.

Hofstede, P. 1980. Cultures and Consequences. Beverly Hills, CA: SAGE Publications.

Levy, Brian. 1993. Obstacles to developing indigenous small and medium enterprises: An empirical assessment. The World Bank Economic Review 7, 1: 65-83.

Lin See Yan. 1994. The financing of small-scale enterprises in Malaysia, Proceedings of The 1st National Conference for SMIs. Organised by Malaysian Chinese Association (MCA).

Mahmood, Abdullah. 1993. Factors affecting small business managers' participation in educational programmes. Journal of International Business and Entrepreneurship. 2, 2: 65-81. 
Malaysia. 1966. First Malaysia Plan 1966-1970. Kuala Lumpur: Economic Planning Unit, Prime Minister's Department.

Malaysia. 1971. Second Malaysia Plan 1971-1975. Kuala Lumpur: Economic Planning Unit, Prime Minister's Department.

Mason, Colin and Richard Harrison. 1994. Informal venture capital in the U.K. In Hughes, A. and D.J. Storey, eds. Finance and the small firm. London: Routledge: 64-111.

Md. Salleh, Ismail. 1990. Small and medium scale industrialisation: problems and prospects. In Esderts, H. and I. Md. Salleh, eds., Small-scale industries and strategies for rural industrialisation - The Malaysian, experience. Kuala Lumpur: Friedrich-Ebert-Stiftung: 1-24.

Murray, G. 1999. Early-stage venture capital funds, scale economies and public support. Paper (unpublished) presented at the International Conference on Funding Gap Controversies, The University of Warwick, April 12-13.

Myers, S. and N. Majluf. 1984. Corporate financing and investment decisions when firms have information that investors do not have. Journal of Financial Economics (June): 187-222.

NERA. 1990. An evaluation of the loan guarantee scheme. Research Paper No.74, Department of Employment.

Oakey, R. 1991. Government policy towards high technology: Small firms beyond the year 2000. In Curran, J. and R.A. Blackburn, eds., Paths of Enterprise: The Future of The Small Business, London: Routledge: 128-148.

OECD. 1999a. Foreign direct Investment and recovery in South-East Asia. OECD Proceedings.

OECD. 1999b. Asia and the global crisis - The industrial dimension. OECD Proceedings. 
Peterson, Rein and Joel Shulman. 1987. Capital structure of growing small firms: A 12-country study on becoming bankable. International Small Business Journal. 5, 4: 10-22.

Siegel, Sidney and N. John Castellan. 1988. Nonparametric statistics for behavioural sciences, 2nd ed. New York: McGraw-Hill.

Stanworth, John and Colin Gray. 1991. Bolton 20 years on: The small firm in the 1990s. London: Paul Chapman.

Storey, David. 1994. Understanding the small business sector. London: Routledge.

Sudman, Seymour and Norman Bradburn. 1982. Asking questions: A practical guide to questionnaire design. San Francisco, CA: Jossey-Bass.

Tamari, Meir. 1980. The financial structure of the small firm - An international comparison of corporate accounts in the U.S.A., France, U.K., Israel, and Japan. American Journal of Small Business IV, 4 (Spring): 20-34.

University of Cambridge. 1992. The state of British enterprise: growth, innovation and competitive advantage in small and medium-sized firms. University of Cambridge: Small Business Centre.

Westhead, P. and D. Storey. 1997. Training Provision and the Development of Small and Medium-Sized Enterprises. DfEE Research Report No. 26. London: HMSO.

Wilson, L. 1995. Occupational Standards for Small Firms. Executive Development 8, 6: 18-20.

Wilson Committee. 1979. Committee to review the functioning of financial institutions, Vol.2. London: HMSO. 